Correction

\title{
Correction: Popp, J., et al. Biofuels and Their Co-Products as Livestock Feed: Global Economic and Environmental Implications. Molecules 2016, 21, 285.
}

\author{
József Popp ${ }^{1,+}$, Mónika Harangi-Rákos ${ }^{1, \dagger}{ }^{\dagger}$, Zoltán Gabnai ${ }^{2, \dagger}$, Péter Balogh ${ }^{1,+}$, \\ Gabriella Antal ${ }^{1, *,+}$ and Attila Bai ${ }^{2, \dagger}$ \\ 1 Institute of Sectoral Economics and Methodology, Faculty of Economics and Business, \\ University of Debrecen, Debrecen 4032, Hungary; popp.jozsef@econ.unideb.hu (J.P.); \\ rakos.monika@econ.unideb.hu (M.H.-R.); balogh.peter@econ.unideb.hu (P.B.) \\ 2 Institute of Business Economics, Faculty of Economics and Business, University of Debrecen, Debrecen 4032, \\ Hungary; zoltangabnai@gmail.com (Z.G.); bai.attila@econ.unideb.hu (A.B.) \\ * Correspondence: antal.gabriella@econ.unideb.hu; Tel.: +36-20-496-1008 \\ $\dagger$ These authors contributed equally to this work.
}

Academic Editor: Derek J. McPhee

Received: 15 April 2016; Accepted: 21 April 2016; Published: 23 April 2016

The authors wish to make the following correction to their paper [1]. In Figure 3, the measurement units are wrong, and should be billion Litre- $\mathrm{bl} \mathrm{L}$, not million Litre- $\mathrm{mln} \mathrm{L}$. The correct version of Figure 1 is as follows:

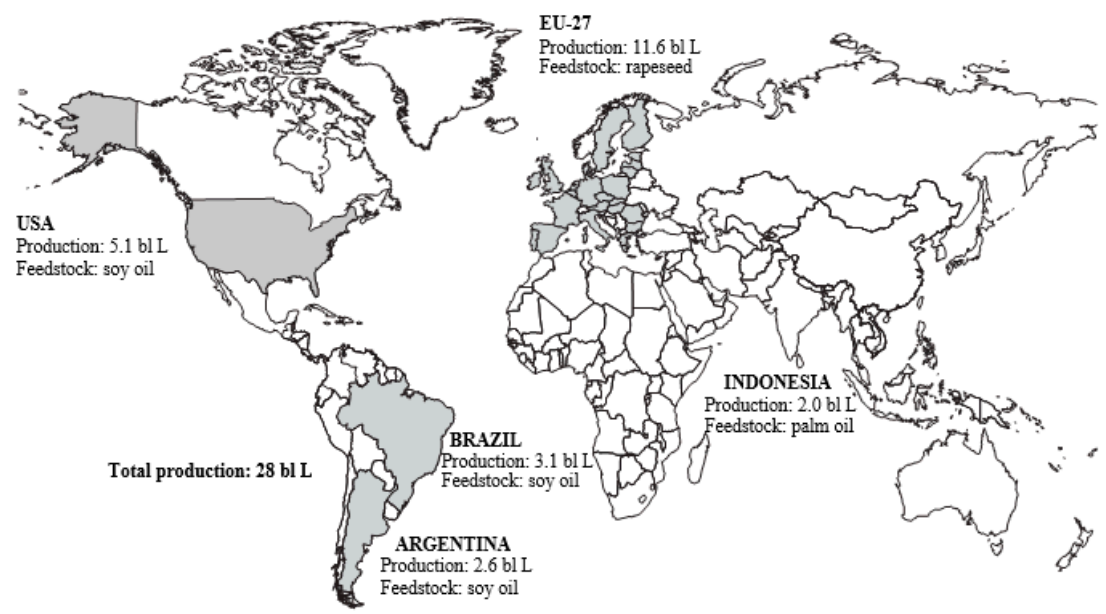

Figure 1. Word biodiesel production, average 2012-2014 [5].

The authors would like to apologize for any inconvenience caused to the readers by this change.

\section{Reference}

1. Popp, J.; Harangi-Rákos, M.; Gabnai, Z.; Balogh, P.; Antal, G.; Bai, A. Biofuels and Their Co-Products as Livestock Feed: Global Economic and Environmental Implications. Molecules 2016, 21, 285. [CrossRef] [PubMed]

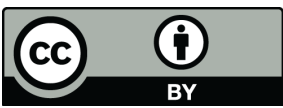

(C) 2016 by the authors; licensee MDPI, Basel, Switzerland. This article is an open access article distributed under the terms and conditions of the Creative Commons Attribution (CC-BY) license (http://creativecommons.org/licenses/by/4.0/). 